\title{
High Avidity IFN-neutralizing Antibodies in Pharmaceutically Prepared Human IgG
}

\author{
Christian Ross, ${ }^{\star}$ Morten Svenson, ${ }^{\ddagger}$ Morten B. Hansen, ${ }^{\neq \$}$ Gunhild L. Vejlsgaard, ${ }^{\star}$ and Klaus Bendtzen ${ }^{\star}$ \\ ${ }^{*}$ Laboratory for Clinical Interferon Research, Department of Dermatology, Rigshospitalet, Copenhagen; ${ }^{\ddagger}$ Laboratory of Medical \\ Immunology, Department of Rheumatology, Rigshospitalet, Copenhagen; and ${ }^{\S}$ Department of Infectious Diseases, \\ Rigshospitalet, Copenhagen
}

\begin{abstract}
This paper demonstrates and characterizes naturally occurring antibodies to interferon (IFN) in human IgG preparations. In vitro neutralization of the antiviral effect of IFN $\alpha$ and IFN $\beta$, but not IFN $\gamma$, was observed in 12 of 15 normal IgG preparations. The neutralizing capacity was higher against rIFN $\alpha 2 A$ and rIFN $\alpha 2 C$ than against lymphoblastoid IFN $\alpha$ and IFN $\beta$. Frühsommer meningoencephalitis hyperimmune IgG and hepatitis-B hyperimmune IgG showed potent neutralization, whereas anti-rhesus D-, anti-rabies-, and anti-tetanus IgG showed weak neutralization. Saturable binding of ${ }^{125}$ I-rIFNa $2 A$ was demonstrated only in those IgG preparations found to neutralize the antiviral effect of IFN. Significant correlation between IFN binding and neutralization capacity was observed. The antibodies bound with Fab to rIFNa2A with an avidity of $\sim 30 \mathrm{pM}$; the majority was of the IgG1 subclass. Maximum binding capacity was $490 \mathrm{pg}$ rIFN $\alpha 2 \mathrm{~A} / \mathrm{mg}$ IgG. Cross-binding of rIFN $\alpha 2 C$, lyIFN $\alpha N 1$ and IFN $\beta$ occurred with 10 and 100-200 times lower activities than that of rIFN $\alpha 2 A$. There was no cross-binding with rIFN $\gamma$ or rIL-6. IgG preparations containing anti-IFN antibodies blocked the binding of ${ }^{125} \mathrm{I}$ rIFN $\alpha 2 A$ to A549 cells. In conclusion, pharmaceutically prepared human IgG preparations contain variable but significant levels of high-avidity IFN $\alpha$ and IFN $\beta$ neutralizing antibodies. (J. Clin. Invest. 1995. 95:1974-1978.) Key words: interferons • human immune globulin • IgG • autoantibody - cytokines
\end{abstract}

\section{Introduction}

Based on antigenic properties, human interferons (IFNs) can be divided into three main groups: IFN $\alpha$, IFN $\beta$, and IFN $\gamma$. Because of the antiviral, antitumor, and immunoregulatory effects, IFNs have been used in a variety of diseases with varying clinical responses. A significant therapeutic problem has been the development of neutralizing antibodies in IFN-treated patients, which has been associated with response failure (1-4).

Address correspondence to Klaus Bendtzen, M.D., Laboratory of Medical Immunology, RHIMA Center 7411, National University Hospital (Rigshospitalet), 20 Tagensvej, DK-2200 Copenhagen N, Denmark. Phone: 35457548; FAX: 35457554.

Received for publication 1 October 1994 and in revised form 17 January 1995.

J. Clin. Invest.

(c) The American Society for Clinical Investigation, Inc. $0021-9738 / 95 / 05 / 1974 / 05 \$ 2.00$

Volume 95, May 1995, 1974-1978
The immunogenicity of rIFN $\alpha 2 \mathrm{~A}$ seems to be higher than that of other IFN $\alpha$ preparations (5).

Antibodies to IFNs have been reported in a few patients suffering from viral diseases, such as varicella zoster and viral hepatitis, and autoimmune diseases, such as systemic lupus erythematosus, chronic arthritis, and type I diabetes (6-11). Low levels of antibodies neutralizing IFN $\alpha, \operatorname{IFN} \beta$, and IFN $\gamma$ in vitro have also been reported in healthy blood donors $(10,12,13)$. It is not clear, however, whether these antibodies can be regarded as specific autoantibodies ( $\mathrm{aAb}$ ) to IFNs (13). Immunoglobulin therapy has been reported to be beneficial in many infectious and immunoinflammatory diseases, and various IFN species may be pathogenetically involved in some of these diseases $(14,15)$. Recently, a pharmaceutical preparation of normal human IgG was found to suppress the antiviral effect of IFN $\alpha(12)$.

In this paper, we have characterized IFN-binding and -neutralizing autoantibodies in normal and hyperimmune human IgG preparations.

\section{Methods}

Human IgG preparations. Five batches of normal human IgG from each of three manufacturers were used. (a) $30 \mathrm{mg} / \mathrm{ml}$ Sandoglobulin ${ }^{\circledR}$ (S1S5) (Sandoz, Copenhagen, Denmark); (b) $50 \mathrm{mg} / \mathrm{ml}$ Gammagard ${ }^{\circledR}$ (G1-G5) (Baxter, Allerød, Denmark); and (c) $50 \mathrm{mg} / \mathrm{ml}$ Nordimmun ${ }^{\circledR}$ (N1-N5) (Novo Nordisk, Bagsværd, Denmark). Sandoglobulin ${ }^{\circledR}$ was produced from a plasma pool of over 8,000 Swiss donors and Gammagard ${ }^{\circledR}$ from over 8,000 North American donors, both by alcohol precipitation. Nordimmun ${ }^{\circledR}$ was prepared by polyethylene glycol (PEG) ${ }^{1}$ precipitation of a plasma pool of at least 2,000 Danish donors.

FSME-Bulin ${ }^{\circledR}$ (Frühsommer meningoencephalitis IgG; FSME), $100-170 \mathrm{mg} / \mathrm{ml}$, and hepatitis-B-immunoglobulin (anti-HBsAg 200 i.e.), $100-170 \mathrm{mg} / \mathrm{ml}$, were from Behring. Human anti-D immunoglobulin, (Rhesuman Berna), $200 \mathrm{mg} / \mathrm{ml}$, was from Institut Serotherapique et Vaccinal Suisse Berne, Switzerland. Rabies immune globulin, 130 $\mathrm{mg} / \mathrm{ml}$, was from Pasteur Mérieux Serums \& Vaccins, Lyon, France. All the above hyperimmune IgG preparations were donated by the State Serum Institute, Copenhagen, Denmark.

Cytokines and antibodies. Recombinant IFN $\alpha 2 \mathrm{~A}$ (rIFN $\alpha 2 \mathrm{~A}$; Rocer$\left.{ }^{\circ}{ }^{\circledR}\right), \operatorname{rIFN} \gamma$, and monoclonal antibodies ( $\mathrm{mAb}$ ) against rIFN $\alpha 2 \mathrm{~A}$ were generously donated by G. Garotta and D. Gillesen (Hoffman La Roche, Basel, Switzerland). rIFN $\alpha 2 A$ was titrated against Int. Std. GxA01901-535, and rIFN $\gamma$ was titrated against Int. Std. Gg23-901-530. Recombinant IFN $\alpha 2 \mathrm{C}$ (rIFN $\alpha 2 \mathrm{C}$ ) was kindly donated by G. R. Adolf, Bender, Vienna, Austria and titrated against Int. Std. GxA01-901-535. Lymphoblastoid IFN Wellferon ${ }^{\circledR}$ (ly-IFN $\left.\alpha \mathrm{N} 1\right)$ was generously donated by Wellcome Denmark and C. Brand (Wellcome Int., Beckenham, UK); it was titrated against Int. Std. Ga23-901-532. Recombinant IFN $\beta$ (rIFN $\beta$ ) was a kind donation from Dr. Rentschler Arzneimittel (Laupheim, Germany). International standards were donated by the National Institute

1. Abbreviations used in this paper: ANB, antiviral neutralization bioassay; EMC, encephalomyocarditis; PEG, polyethylene glycol. 
of Allergy and Infectious Diseases, NIH (Bethesda, MD). Recombinant human IL-6 (rIL-6) was donated by Sandoz (Basel, Switzerland).

Antiviral neutralization bioassay (ANB). ANB was performed using A549 cells (CCL 185, American Type Culture Collection, Bethesda, MD) or human fibroblasts isolated from patients suffering from cutaneous $\mathrm{T}$ cell lymphoma after 4-mm punch biopsies according to standard procedures. Encephalomyocarditis (EMC) virus donated by A. R. Thomsen (Institute of Microbiology and Immunology, University of Copenhagen, Denmark). In brief, cells were seeded in microtrays at a concentration of 10,000 cells/well and incubated at $37^{\circ} \mathrm{C}$ in a $5 \% \mathrm{CO}_{2}$ air atmosphere. The IFN $\alpha$ and IFN $\beta$ preparations were added at a concentration of $3 \mathrm{IU} / \mathrm{ml}$; IFN $\gamma$ was used at a concentration of $10 \mathrm{IU} / \mathrm{ml}$. After $24 \mathrm{~h}$ of incubation, EMC virus was added at a concentration which caused $100 \%$ cell death after $26 \mathrm{~h}$. After another $24 \mathrm{~h}$, the antiviral effect of IFN was measured using the 3-(4,5 dimethyl thiazol-2-yl)2,5-difenyl tetrazolium bromid (MTT) assay as described (16). The IgG preparations were marginally toxic to both A549 cells and human fibroblasts, but only at concentrations above $15 \mathrm{mg} / \mathrm{ml}$.

Inhibition of IFN bioactivity by IgG. Screening for IFN neutralizing activity was carried out in the ANB. IgG was diluted in HAM F12 medium. Neutralization was determined by tests of twofold dilutions of IgG and quantitated as the reciprocal value of the dilution of $15 \mathrm{mg} \mathrm{IgG/}$ $\mathrm{ml}$ causing significant reduction of $3 \mathrm{IU} \mathrm{rIFN} \alpha 2 \mathrm{~A} / \mathrm{ml}$ or corresponding amount of other IFN preparations ( $>3$ times SD).

Binding of IFN to IgG. Radiolabeling of $\operatorname{IIFN} \alpha 2 \mathrm{~A}$ was carried out by the chloramine $T$ method $(13,17)$, to a specific activity of $1-2 \times 10^{5}$ $\mathrm{cpm} / \mathrm{ng}$, titrated against the international standard GxA01-901-535. After iodination, ${ }^{125} \mathrm{I}$-rIFN $\alpha 2 \mathrm{~A}$ was chromatographed on Sephadex G75 superfine microcolumns to remove aggregates and salt fractions. Preserved receptor binding capacity and antiviral activity of ${ }^{125}$ I-rIFN $\alpha 2 \mathrm{~A}$ were confirmed on A549 cells.

IgG preparations and the international standard IFN $\alpha 2 \mathrm{~A}$ mAb werc diluted in $0.02 \mathrm{M}$ phosphate-buffered saline, $\mathrm{pH} 7.4$ (PBS), containing $0.1 \%$ gelatin, $0.1 \%$ Triton X-100 (PBS-GTX), or in RPMI 1640 for use in ANB, and coincubated with ${ }^{125}$ I-labeled and unlabeled rIFN $\alpha 2 \mathrm{~A}$. Coincubation was carried out at room temperature followed by overnight incubation at $4^{\circ} \mathrm{C}$ in $100 \mu \mathrm{l}$ containing $3,000 \mathrm{cpm}$ of ${ }^{125} \mathrm{I}-\mathrm{rIFN} \alpha 2 \mathrm{~A}$ with or without $>200$ times excess of unlabeled rIFN $\alpha 2 \mathrm{~A}$.

Binding of IgG to rIFN $\alpha 2 \mathrm{~A}$ was analyzed by molecular size chromatography at $4^{\circ} \mathrm{C}$ by the use of columns containing $10 \mathrm{ml}$ of Sephadex superfine G75 (Pharmacia, Uppsala, Sweden) with a running buffer of PBS-GTX or RPMI 1640 (12).

Binding of IgG to IIFN $\alpha 2 \mathrm{~A}$ was also investigated by use of IgGFc affinity chromatography on columns with $500 \mu$ l protein $\mathrm{G}$ Sepharose CL-4B (Pharmacia). Bound and free tracer were separated at $4^{\circ} \mathrm{C}$ with PBS-GTX as running buffer. Elution of bound material was carried out using $100 \mathrm{mM}$ glycine- $\mathrm{HCl}, \mathrm{pH} 2.4$. Nonspecific binding was assessed in the presence of $200 \mathrm{ng}$ unlabeled rIFN $\alpha 2 \mathrm{~A}$.

The binding potential was defined as the reciprocal value of the dilution of $15 \mathrm{mg} \mathrm{IgG/ml} \mathrm{causing} \mathrm{significant} \mathrm{binding} \mathrm{of} \mathrm{3,000} \mathrm{cpm/100}$ $\mu \mathrm{l}$ of ${ }^{125} \mathrm{I}$-rIFN $\alpha 2 \mathrm{~A}$ ( $>3$ times SD). Radioactivity was determined with an error $<5 \%$ in a gamma counter ( 1272 CliniGamma, LKB, Wallac, OY, Finland).

Avidities were measured as previously described (18). ${ }^{125}$ I-rIFN $\alpha 2 \mathrm{~A}$ was used at concentrations from 40 to $400 \mathrm{pg} / \mathrm{ml}$. Unlabeled rIFN $\alpha 2 \mathrm{~A}$ was added up to a maximum of $50 \mathrm{ng} / \mathrm{ml} .{ }^{125} \mathrm{I}-\mathrm{rIFN} \alpha 2 \mathrm{~A}$ and unlabeled rIFN $\alpha 2 \mathrm{~A}$ were titrated against the international standard. Fixed IgG levels were titrated against varying tracer and competitor concentrations using protein $\mathrm{G}$ chromatography.

IgG subclasses. IgG subclass-specific affinity chromatography of IFN $\alpha$ antibody positive IgG preparations was carried out in microcolumns containing specific antibodies to human IgG1 (SH161-28-P1), IgG2 (SH162-59-P1), IgG3 (SH163-04-P3), or IgG4 (SH164-10-P3) (Janssen Biochemica, Beerse, Belgium). These antibodies were coupled to divinyl sulfone-activated agarose beads (Mini Leak ${ }^{\circledR}$, Kem-En-Tec, Copenhagen, Denmark) with 6\% (wt/vol) PEG mw 6,000 (Merck, Darmstadt, Germany) in $0.3 \mathrm{M} \mathrm{NaHCO}_{3} / \mathrm{NaOH}, \mathrm{pH}$ 8.6. Blocking of excess active groups was done with $0.2 \mathrm{M}$ ethanolamine/ $\mathrm{HCl}, \mathrm{pH}$ 9.0. The coupling yield was $65-90 \%$. Column capacities were assessed by investigating a serum pool $(n=22)$ with known IL-1 $\alpha$ antibody subclass distribution $(19,20)$. They were found to be $50,140,200$, and $300 \mu \mathrm{l}$ serum, respectively. $5 \mu \mathrm{l}$ of serum diluted in $50 \mu \mathrm{l}$ running buffer were applied on each column.

IgG Fab fragments. Papain-agarose (Sigma Chemical Co., St. Louis, $\mathrm{MO}$ ), $20 \mathrm{mg}$, in $10 \mathrm{mM} \mathrm{L-cysteine} \mathrm{and} 2 \mathrm{mM}$ EDTA was incubated for $2 \mathrm{~h}$ at $37^{\circ} \mathrm{C}$ followed by washing with $2 \mathrm{nM}$ EDTA. IgG preparations S4, B5 and N5 were diluted to $25 \mathrm{mg}$ in $1 \mathrm{ml}$ of PBS, $2 \mathrm{mM}$ EDTA, and incubated for $18 \mathrm{~h}$ at $30^{\circ} \mathrm{C}$. The supernatants were applied on Sephadex G75 columns and eluted with PBS. Fractions containing molecules above $30 \mathrm{kD}$ were pooled and concentrated to the original volume by dialysis against powdered PEG 20,000 .

Binding of IFN to A549 cells. A549 cells were grown to confluence $(\sim 600,000$ cells/well) in six well microtiter plates (Nunc, Roskilde, Denmark). FSME, S4 and N1 were incubated for $1 \mathrm{~h}$ at $37^{\circ} \mathrm{C}$ with $10,000 \mathrm{cpm}$ of ${ }^{125}$ I-rIFN $\alpha 2 \mathrm{~A}$ in $750 \mu \mathrm{l}$ HAM F12. Gentle washing was carried out 3 times at $4^{\circ} \mathrm{C}$ in PBS, after which the cells were lysed in $2.5 \mathrm{M} \mathrm{NaOH}, 0.1 \%$ Triton $\mathrm{X}-100$. Controls without IgG were processed in parallel.

\section{Results}

\section{Inhibition of the antiviral effect of IFN by human $\operatorname{IgG}$}

Significant neutralization of IFN $\alpha$ was achieved with 12 of 15 normal human IgG preparations at concentrations from 0.6-15 $\mathrm{mg} / \mathrm{ml}$. The neutralizing activity could be reversed by addition of excess rIFN $\alpha 2 \mathrm{~A}$. Titrations on human fibroblasts gave similar results.

To study the specificity of the IFN neutralization, rIFN $\alpha 2 \mathrm{~A}$, rIFN $\alpha 2 \mathrm{C}, 1 \mathrm{y}-\mathrm{IFN} \alpha \mathrm{N} 1$, and IFN $\beta$, at concentrations inducing $90 \%$ protection against challenge virus, were incubated with serial dilutions of IgG preparation. Fig. 1, upper panel, shows the results using FSME at concentrations from $7.5 \mathrm{mg} / \mathrm{ml}$ and twofold dilution to $50 \mu \mathrm{g} / \mathrm{ml}$. A $50 \%$ reduction in antiviral activity was observed at IgG concentrations of $0.5 \mathrm{mg} / \mathrm{ml}$ (rIF$\mathrm{N} \alpha 2 \mathrm{~A}), 1.5 \mathrm{mg} / \mathrm{ml}$ (rIFN $\alpha 2 \mathrm{C}$ ), $2.5 \mathrm{mg} / \mathrm{ml}$ (ly-IFN $\alpha \mathrm{N} 1$ ), and $7.9 \mathrm{mg} / \mathrm{ml}(\mathrm{rIFN} \beta)$. FSME did not neutralize the antiviral effect of rIFN $\gamma$ (not shown). A pool of normal human IgG showed a similar inhibitory pattern, but higher IgG levels were needed for neutralization (Fig. 1, lower panel).

Binding of IFN to human IgG. Molecular size chromatography demonstrated binding of ${ }^{125} \mathrm{I}$-rIFN $\alpha 2 \mathrm{~A}$ in the $12 \mathrm{IgG}$ preparations that neutralized IFN activity. All batches of Gammagard ${ }^{\circledR}$ and Sandoglobulin ${ }^{\circledR}$ demonstrated significant binding ranging from $47-90 \%$ (Fig. 2). Two batches of Nordimmun ${ }^{\circledR}$ showed positive binding, one was borderline positive, and two showed no significant binding. Blocking antibodies were not detected when investigating pools of anti-IFN $\alpha$ positive and -negative IgG preparations, respectively.

Titrations of normal IgG preparations showed binding capacities between 0 and 40. FSME bound significantly at a concentration of $75 \mu \mathrm{g} / \mathrm{ml}$ corresponding to a binding capacity of 200. Anti-HBsAg IgG had a binding capacity of 80 and the anti-D and rabies IgG preparations contained low levels of antirIFN $\alpha 2 \mathrm{~A}$ with binding capacities of 5 and 10 , respectively. Titrations using anti-IFN $\alpha$ mAb standard showed a detection limit of binding to rIFN $\alpha 2 \mathrm{~A}$ of 0.45 international neutralizing units (INU) $/ \mathrm{ml}$, binding $11 \%$ of the $3,000 \mathrm{cpm}{ }^{125} \mathrm{I}-\mathrm{rIFN} \alpha 2 \mathrm{~A}$ used for chromatography. $80 \%$ of the tracer was bound at a concentration of $30 \mathrm{INU} / \mathrm{ml}$, indicating that the most potent normal IgG preparation, at a concentration of $15 \mathrm{mg} / \mathrm{ml}$, possessed a binding capacity corresponding to $30 \mathrm{INU} / \mathrm{ml}$ of the cytokine.

There was a highly significant linear correlation between 

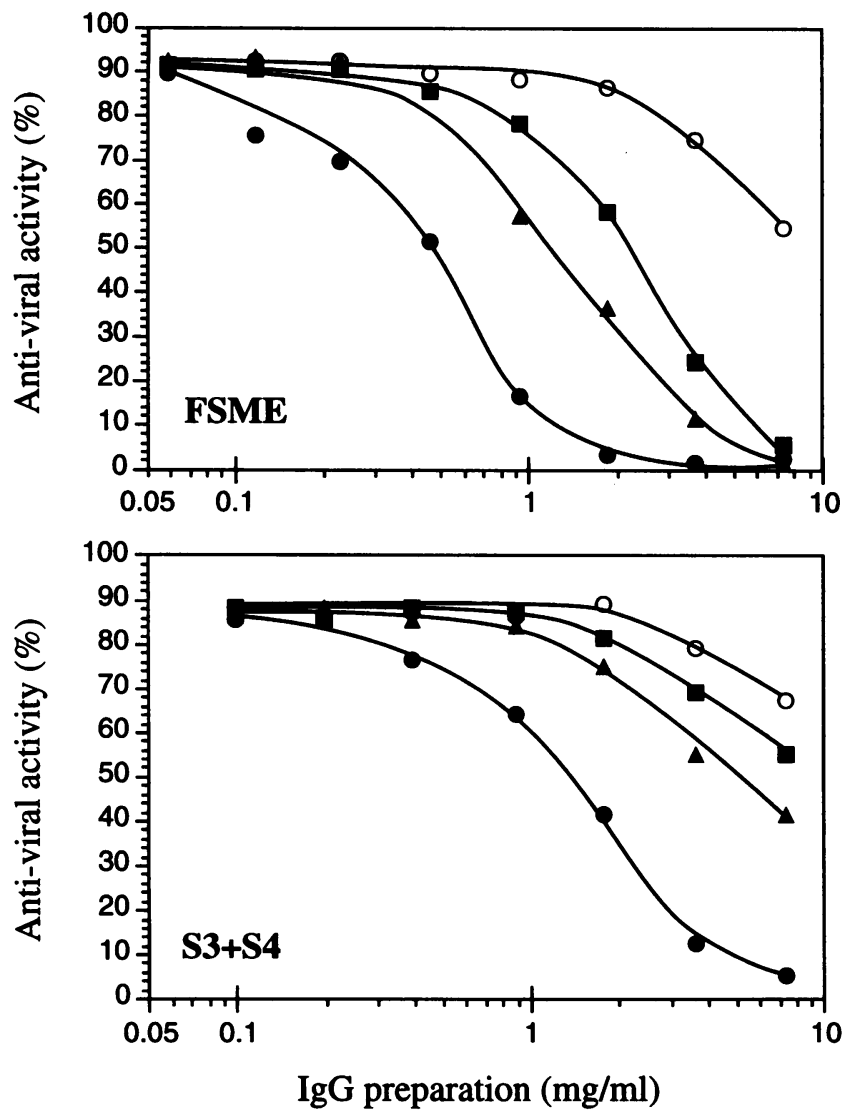

Figure 1. Reduction of IFN-induced antiviral activity afforded by Frühsommer meningoencephalitis IgG (FSME) or Sandoglobulin ${ }^{\otimes}(S 3+S 4)$. FSME and the S3+S4 pool were tested against $\operatorname{rIFN} \alpha 2 \mathrm{~A}(\bullet), \operatorname{rIFN} \alpha 2 \mathrm{C}$ $(\Delta)$, ly-IFN $\alpha \mathrm{N} 1$ ( $\bullet$ ), and $\operatorname{rIFN} \beta$ (O); each IFN preparation was tested at the lowest concentration inducing $90 \%$ protection against EMC virus.

the ability of normal IgG to bind and to neutralize IFN $\alpha$ (Fig. 3 ). More than $80 \%$ of the binding was achieved after $10 \mathrm{~min}$ at $37^{\circ} \mathrm{C}$, whereas $<30 \%$ bound after $10 \mathrm{~min}$ at $4^{\circ} \mathrm{C}$. In the presence of 500-fold excess rIFN $\alpha 2 \mathrm{~A}$, dissociation of the antigen/antibody complex was slow ( $\mathrm{T} / 2>48 \mathrm{~h}$ at $\left.37^{\circ} \mathrm{C}, n=5\right)$.

IgG subclass distribution of IFN $\alpha$ binding antibodies. Affinity chromatography using protein-G columns demonstrated recovery of $>90 \%$ as compared with Sephadex G75. IgG subclass-specific affinity chromatography, carried out on a pool of anti-IFN $\alpha$ positive IgG preparations, showed that the majority of antibodies was of the IgG1 subclass. Only traces of IgG2, IgG3, and IgG4 were found (Fig. 4).

Binding of IFNa to Fab fragments of human IgG. After papain treatment of IgG, $\sim 50 \%$ of ${ }^{125}$ I-rIFN $\alpha 2 \mathrm{~A}$ binding was recovered after Sephadex G75 chromatography. However, almost no binding was retrieved, if Fab fragments were excluded from recovery by the use of protein $\mathrm{G}$ (see Fig. 4).

Specificity of the IFN $\alpha$ binding antibodies. Using IgG preparation $\mathrm{S} 4$ and ${ }^{125} \mathrm{I}-\mathrm{rIFN} \alpha 2 \mathrm{~A}$ at a $\mathrm{B} / \mathrm{F}$ ratio of 0.64 , competition with unlabeled IFN preparations revealed a clear pattern of specificity. Unlabeled $\mathrm{rIFN} \alpha 2 \mathrm{~A}, 0.1 \mathrm{ng} / \mathrm{ml}$, reduced the $\mathrm{B} / \mathrm{F}$ value by $>50 \%$, while $1 \mathrm{ng} / \mathrm{ml}$ was needed for the same reduction by rIFN $\alpha 2 \mathrm{C}$ or ly-IFN $\alpha \mathrm{N} 1$ (Fig. 5 ). $\operatorname{rIFN} \beta$ also blocked the binding of ${ }^{125} \mathrm{I}-\mathrm{rIFN} \alpha 2 \mathrm{~A}$, but to a lesser extent than the IFN $\alpha$ preparations. rIL- 6 and rIFN $\gamma$ failed to affect the binding.

IgG induced blocking of IFN binding to A549 cells. FSME,

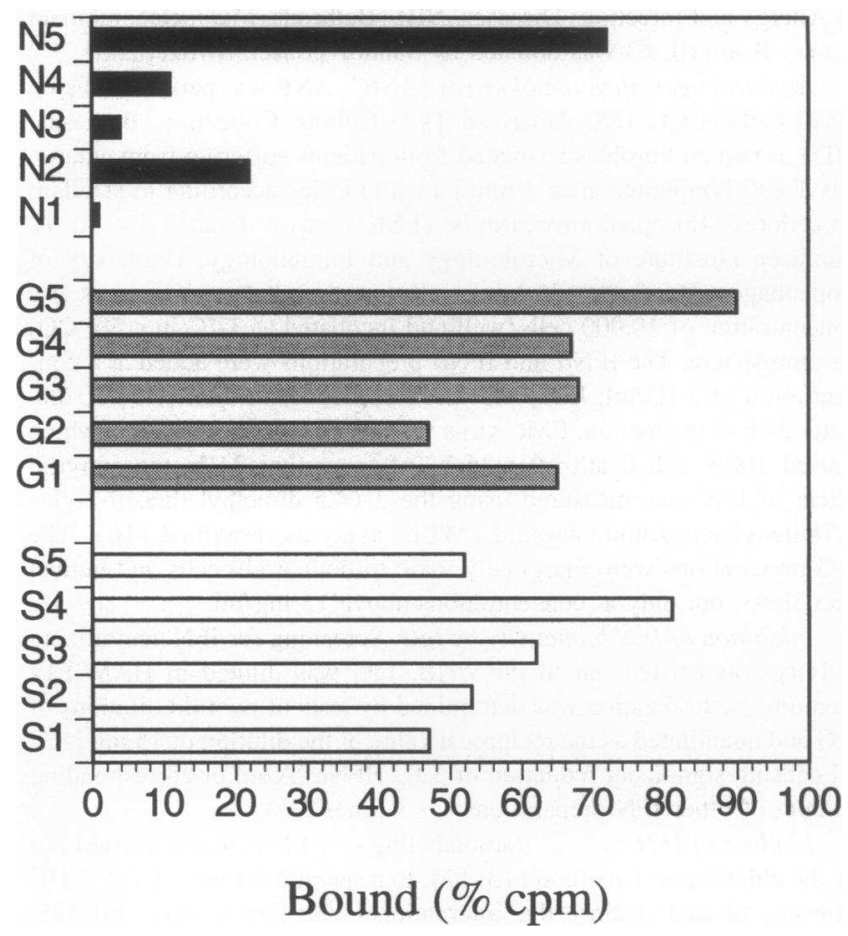

Figure 2. Binding of ${ }^{125} \mathrm{I}-\mathrm{rIFN} \alpha 2 \mathrm{~A}$ to human IgG measured by molecular size chromatography on Sephadex G75 columns. ${ }^{125}$ I-rIFN $\alpha 2 \mathrm{~A}, 3,000$ $\mathrm{cpm}$ in $100 \mu \mathrm{l}(=100 \%)$, and $10 \mathrm{mg} / \mathrm{ml} \mathrm{IgG}$ were applied on each column. S1-S5: Sandoglobulin ${ }^{\circledR}$ preparations 1-5; G1-G5: Gammagard ${ }^{\circledR}$ preparations 1-5; N1-N5: Nordimmun ${ }^{\circledR}$ preparations 1-5.

$10 \mathrm{mg} / \mathrm{ml}$, reduced the binding of ${ }^{125} \mathrm{I}-\mathrm{rIFN} \alpha 2 \mathrm{~A}$ to A549 cells by $78 \%$, whereas the same concentration of S4 IgG inhibited by $60 \%$. In contrast, the N1 IgG preparation, which was rIFN $\alpha 2 \mathrm{~A}$ antibody negative, failed to interact with the binding.

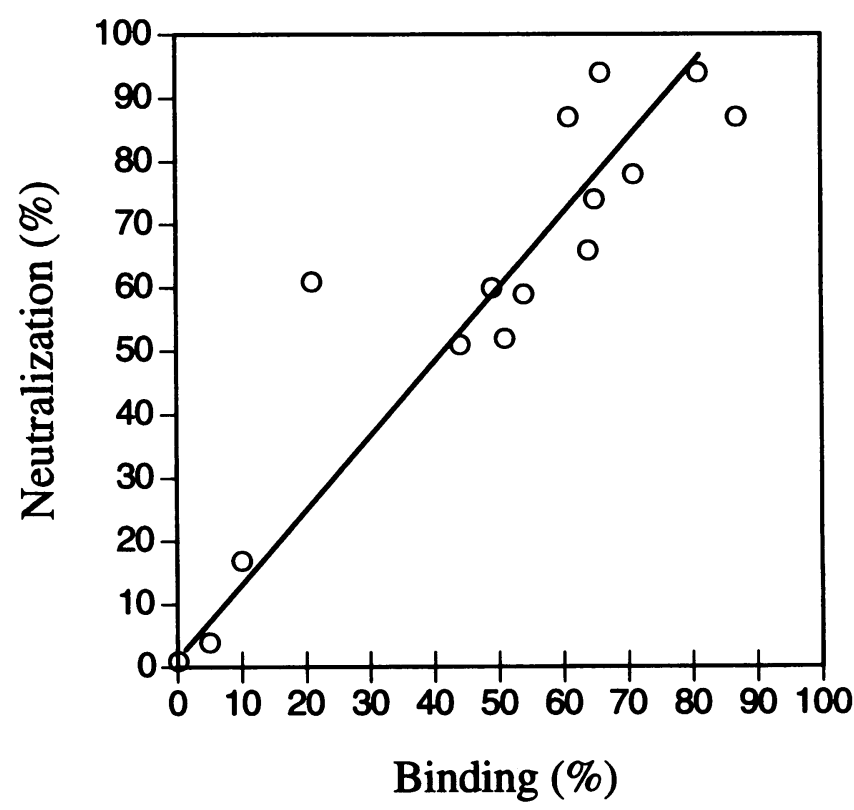

Figure 3. Linear correlation between binding and neutralization of IFN $\alpha$ using normal IgG. Binding was measured by Sephadex G75 column chromatography and neutralization by ANB. Spearman rank correlation: $r=0.89 ; P<0.0001$. 


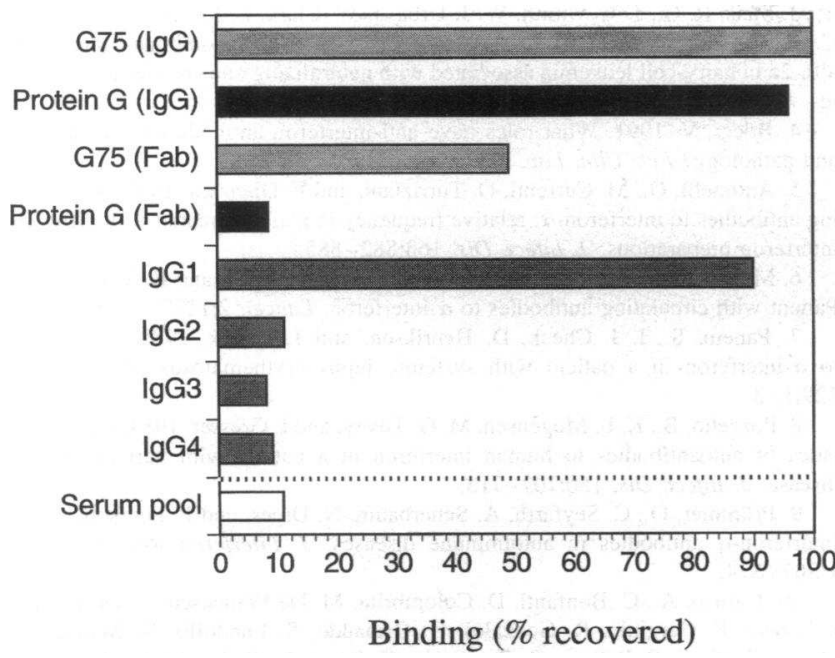

Figure 4. (Upper panel) IgG subclasses binding to ${ }^{125} \mathrm{I}-\mathrm{rIFN} \alpha 2 \mathrm{~A}$ using molecular size chromatography and affinity chromatography. $G 75$ $(I g G)$, molecular size chromatography on Sephadex G75 using untreated IgG. Protein $G(\mathrm{IgG})$, protein-G affinity chromatography of IgG. $G 75(F a b)$, molecular size chromatography on Sephadex G75 using papain-pretreated IgG. Protein $G(F a b)$, protein-G affinity chromatography of papain-treated IgG. IgG1-IgG4, anti-IgG1-, IgG2-, IgG3-, IgG4-specific affinity chromatography of IgG. (Lower panel) The serum pool was from 40 healthy adults and used as $50 \%$ ( $\mathrm{vol} / \mathrm{vol}$ ) in $100 \mu \mathrm{l}$.

Avidities and binding capacities of the antibodies to IFN $\alpha$ As shown in Table I, the avidities of FSME and three normal antibody-positive IgG preparations varied only slightly: $K_{\mathrm{d}} \approx 30$ pM. In contrast, the maximum binding capacities varied considerably: from 27 to $490 \mathrm{pg} / \mathrm{mg}$ IgG (Table I). The avidities were not influenced by varying the test concentrations of IgG to bind from 100 to $1,000 \mathrm{pg} / \mathrm{ml}$ of ${ }^{125} \mathrm{I}-\mathrm{rIFN} \alpha 2 \mathrm{~A}$.

Binding of IFN $\alpha$ to human serum. Molecular size and protein-G chromatography demonstrated low binding of ${ }^{125} \mathrm{I}-\mathrm{rIF}$ $\mathrm{N} \alpha 2 \mathrm{~A}$ in a pool of 40 normal serum samples (see Fig. 4).

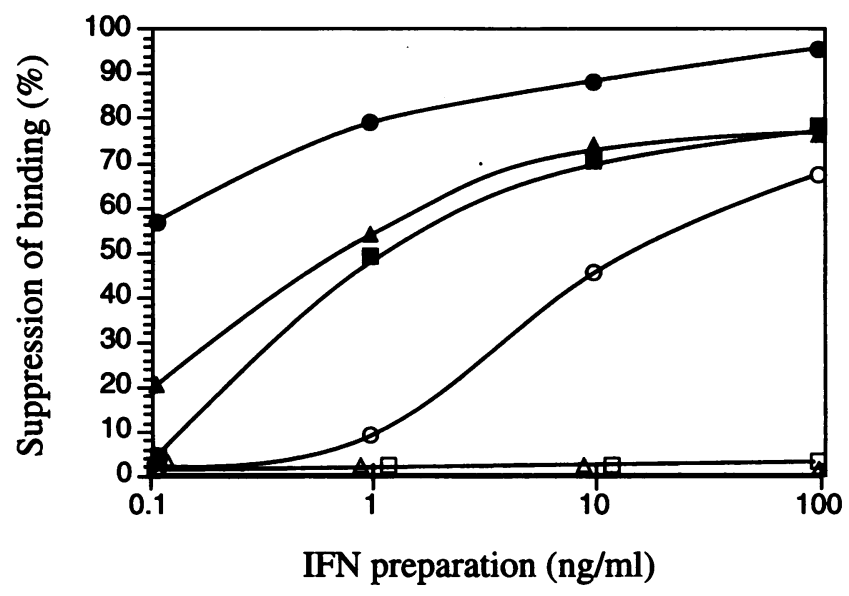

Figure 5. Competition analysis using unlabeled IFN preparations and ${ }^{125}$ I-rIFN $\alpha 2 \mathrm{~A}$ binding to IgG S4. Results are shown as suppression of $B / F$, where the $B / F$ value in the absence of unlabeled cytokine was 0.64 ( $=0 \%$ suppression). $\operatorname{rIFN} \alpha 2 \mathrm{~A}(\bullet) ; \operatorname{rIFN} \alpha 2 \mathrm{C}(\Delta) ;$ ly-IFN $\alpha \mathrm{N} 1$ $(\square) ; \operatorname{rIFN} \beta(O)$; rIFN $\gamma(\Delta)$; rIL-6 (口).
Table I. Avidities and Maximum Binding Capacities of IgG Preparations

\begin{tabular}{lccc}
\hline \multicolumn{1}{c}{ IgG preparation } & IgG (mg/ml) & Kd (pM) & Bmax (pg/mg IgG) \\
\hline Sandoglobulin S4 & 6.5 & 23 & 31 \\
Gammagard G1 $^{\star}$ G1 & 10.8 & 43 & 27 \\
Nordimmun N5 & 9 & 22 & 30 \\
FSME-Bulin & 2 & 28 & 490 \\
\hline
\end{tabular}

When individual sera were investigated, 8 of $\mathbf{4 0}$ serum samples showed minimal specific binding, which did not exceed $20 \%$ of 3,000 cpm of ${ }^{125} \mathrm{I}-\mathrm{rIFN} \alpha 2 \mathrm{~A}$ added to each serum ( $50 \%$ serum in $100 \mu \mathrm{l})$.

\section{Discussion}

More than 10 years ago, antibodies which neutralized IFN $\alpha$, but not IFN $\beta$ or IFN $\gamma$, were reported in a patient with systemic lupus erythematosus (7). Other case reports showed IFN antibodies before treatment in a patient with herpes-zoster and in two cancer patients $(6,21)$. High neutralizing capacity IFN antibodies were detected in a patient with pure red cell aplasia, and non-neutralizing antibodies to $\operatorname{rIFN} \alpha 2 \mathrm{~A}$ of $\operatorname{IgM}$ and IgG type were reported in patients with acute viral hepatitis $(11,22)$.

Naturally occurring antibodies to IFN $\alpha$ and IFN $\beta$ have been reported in Lou/c rats and in inbred mouse strains $(23,24)$. Investigations of autoantibodies to various IFN species in healthy humans have been conflicting. In 1990, naturally occurring antibodies which neutralized the antiviral effect of different IFN preparations were reported (12). Saturability of binding and Fab binding were not conducted and specific binding of immunoglobulin to the IFN species was therefore not demonstrated. Natural antibodies to IFN $\gamma$ have also been reported in sera of healthy donors with increased levels during viral infection (10). These antibodies dose-dependently inhibited rIFN $\gamma$ induced expression of Fc receptor and HLA-DR antigens on $U 937$ cells, but did not neutralize the antiviral effect of IFN $\gamma$ in a viral plaque-reduction assay using HeLa cells challenged with EMC virus (25). Again, saturability and Fab binding were not demonstrated.

The problems concerning detection of autoantibodies to IFN species and to other cytokines have recently been addressed (13, 18). For example, even though human serum immunoglobulins suppress the antiviral activity of both type I and type II IFNs, this suppression does not necessarily correlate with direct binding of IFN to serum factors or inhibition of IFN receptor binding $(12,13)$. It appears, therefore, that serum immunoglobulins may also interfere with the antiviral activity of IFN at the target cell level.

The present study confirms the quantitatively minor specific binding of the IFNs to normal human serum. In contrast, a substantial and high-avidity binding to IFN $\alpha$ was observed in 12 of 15 preparations of pooled normal human IgG. The binding was saturable and occurred primarily or exclusively through the Fab fragments.

The highest concentration of IFN-specific IgG was observed in Frühsommer meningoencephalitis hyperimmune IgG preparations. It is unknown but possible that IFN neutralizing antibodies in such IgG preparations may neutralize the effects of 
IFNs in vivo and hence contribute to therapeutic failure. Different production methods and/or ethnic and climatic differences between the donor populations are also likely explanations for the different levels of IFN antibodies in the IgG preparations. The difference in the binding and the neutralizing capacities of the IFN antibodies against different IFN $\alpha$ preparations correlates with differences in IFN immunogenicity. Thus, it is generally accepted that treatment with rIFN $\alpha$, particularly rIFN $\alpha 2 \mathrm{~A}$, induces higher levels of IFN antibodies than treatment with leukocyte or lymphoblastoid IFN (25).

The discrepancy between the relatively high levels of IFN antibodies in human IgG preparations and the finding of seemingly low levels of specific anti-IFN $\alpha$ IgG in only a few (20\%) of the individual human sera may be explained by the presence in serum of IFN $\alpha /$ anti-IFN $\alpha$ IgG complexes which impede detection of the specific antibodies by added radiolabeled IFN $\alpha$. It is also possible that the avidity of the anti-IFN $\alpha$ IgG molecules in human IgG prepared from more than 1,000 donors may be higher than that of anti-IFN $\alpha$ IgG in individual donors due to a higher degree of polyclonality. Finally, since there was no sign of IgG-IgG interactions blocking the binding of rIFN $\alpha 2 \mathrm{~A}$ to the antibody preparations, it cannot be excluded that nonIgG blocking factors, for example IgM, exist in vivo and that these molecules are removed during the purification of pharmaceutically prepared IgG.

Naturally occurring antibodies to IL- $1 \alpha$ and IL-6 have been demonstrated in healthy donors and in pharmaceutic IgG preparations; these antibodies, along with those against IFN $\alpha$, may be of clinical importance and help to explain the efficacy of high-dose immunoglobulin therapy of certain immunoinflammatory and infectious diseases $(14,18,26)$.

In conclusion, high-avidity antibodies to IFN $\alpha$ and, to a lesser extent IFN $\beta$, are present in the majority of human IgG preparations. The specificities of these autoantibodies reflect the immunogenicity of the different IFN $\alpha$ preparations when used for therapeutic purposes. The presence of these antibodies may be beneficial in high-dose immunoglobulin therapy of conditions with excessive IFN $\alpha$ production. On the other hand, it is theoretically possible that viral diseases may be negatively influenced by these antibodies.

\section{Acknowledgments}

The expert technical assistance of M. Tjalve, S. Melgaard and O. Christensen is gratefully acknowledged. Novo-Nordisk and the Danish Serum Institute kindly donated the IgG preparations.

This study was supported by the Danish Cancer Society, the Aage Bang Foundation, the Danish Medical Research Council and the Danish Biotechnology Programme.

\section{References}

1. Stewart, W. E. 1980. Interferon nomenclature. Nature (Lond.). 286:110. 2. Von Wussow, P., M. Freund, B. Block, H. Diedrich, H. Poliwoda, and H. Deicher. 1987. Clinical significance of anti-IFN- $\alpha$ antibody titres during interferon therapy. Lancet. 2:635-636.
3. Steis, R. G., J. W. Smith, W. J. Urba, J. W. Clark, L. M. Itri, L. M. Evans, C. Schoenberger, and D. L. Longo. 1988. Resistance to recombinant interferon alfa-2a in hairy-cell leukemia associated with neutralizing anti-interferon antibodies. N. Engl. J. Med. 318:1409-1413.

4. Bocci, V. 1991. What roles have anti-interferon antibodies in physiology and pathology? Res. Clin. Lab. 21:79-84.

5. Antonelli, G., M. Currenti, O. Turriziani, and F. Dianzani. 1991. Neutralizing antibodies to interferon- $\alpha$ : relative frequency in patients treated with different interferon preparations. J. Infect. Dis. 163:882-885.

6. Mogensen, K. E., P. H. Daubas, I. Gresser, D. Sereni, and B. Varet. 1981 Patient with circulating antibodies to $\alpha$-interferon. Lancet. 2:1227-1228.

7. Panem, S., I. J. Check, D. Henriksen, and J. Vilcek. 1982. Antibodies to $\alpha$-interferon in a patient with systemic lupus erythematosus. J. Immunol. 129:1-3.

8. Pozzetto, B., K. E. Mogensen, M. G. Tovey, and I. Gresser. 1984. Characteristics of autoantibodies to human interferon in a patient with varicella-zoster disease. J. Infect. Dis. 150:707-713.

9. Prummer, O., C. Seyfarth, A. Scherbaum, N. Drees, and F. Porzsolt. 1989. Interferon- $\alpha$ antibodies in autoimmune diseases. J. Interferon Res. 9, Suppl. 1:S67-S74.

10. Caruso, A., C. Bonfanti, D. Colombrita, M. De Francesco, C. De Rango, I. Foresti, F. Gargiulo, R. Gonzales, G. Gribaudo, S. Landolfo, N. Manca, G. Manni, F. Pirali, P. Pollara, G. Ravizzola, G. Scura, L. Terlenghi, E. Viani, and A. Turano. 1990. Natural antibodies to IFN- $\gamma$ in man and their increase during viral infection. J. Immunol. 144:685-690.

11. Ikeda, Y., G. Toda, N. Hashimoto, N. Umeda, K. Miyake, M. Yamanaka, and K. Kurokowa. 1991. Naturally occurring anti-interferon- $\alpha 2 \mathrm{a}$ antibodies in patients with acute viral hepatitis. Clin. Exp. Immunol. 85:80-84.

12. Ross, C., M. B. Hansen, T. Schyberg, and K. Berg. 1990. Autoantibodies to crude human leucocyte interferon (IFN), native human IFN, recombinant human IFN- $\alpha 2 \mathrm{~b}$ and human IFN- $\gamma$ in healthy blood donors. Clin. Exp. Immunol. 82:57-62.

13. Hansen, M. B., M. Svenson, and K. Bendtzen. 1992. Serum-induced suppression of interferon (IFN) activity. Lack of evidence for the presence of specific autoantibodies to IFN- $\alpha$ in normal human sera. Clin. Exp. Immunol. 88:559-562.

14. Dwyer, J. M. 1992. Manipulating the immune system with immune globulin. N. Engl. J. Med. 326:107-116.

15. Paul, W. E. and R. A. Seder. 1994. Lymphocyte responses and cytokines. Cell. 76:241-251.

16. Hansen, M. B., C. Ross, and K. Berg. 1990. A sensitive antiviral neutralization bioassay for mesuring antibodies to interferons. J. Immunol. Methods. 127:241-248.

17. Mogensen, K. E., and G. Uzé. 1986. Radioiodination of human alpha interferons by the chloramine T method. Methods Enzymol. 119:267-275.

18. Svenson, M., M. B. Hansen, and K. Bendtzen. 1993. Binding of cytokines to pharmaceutically prepared human immunoglobulin. J. Clin. Invest. 92:25332539.

19. Svenson, M., M. B. Hansen, and K. Bendtzen. 1990. Distribution and characterization of autoantibodies to interleukin $1 \alpha$ in normal human sera. Scand. J. Immunol. 32:695-701.

20. Hansen, M. B., M. Svenson, K. Abell, K. Varming, H. P. Nielsen, A. Bertelsen, and K. Bendtzen. 1994. Sex- and age-dependency of IgG auto-antibodies against IL-1 $\alpha$ in healthy humans. Eur. J. Clin. Invest. 24:212-218.

21. Trown, P. W., M. J. Kramer, R. A. Dennin, E. V. Connell, and A. V. Palleroni. 1983. Antibodies to human leucocyte interferons in cancer patients. Lancet. 1:81-87.

22. Prummer, O., N. Frickhofen, W. Digel, H. Heimpel, and F. Porzsolt. 1991. Spontaneous interferon- $\alpha$ antibodies in a patient with pure red cell aplasia and recurrent cutaneous carcinomas. Ann. Hematol. 62:76-80.

23. De Maeyer-Guignard, J., A. Cachard-Thomas, and E. De Maeyer. 1984. Naturally occurring anti-interferon antibodies in Lou/c rats. J. Immunol. 133:775778.

24. De Maeyer-Guignard, J., and E. De Maeyer. 1986. Natural antibodies to interferon-alpha and interferon-beta are a common feature of inbred mouse strains. J. Immunol. 136:1708-1711.

25. Turano, A., A. Balsari, E. Viani, S. Landolfo, L. Zanoni, F. Gargiulo, and A. Caruso. 1992. Natural human antibodies to $\gamma$ interferon interfere with the immunomodulating activity of the lymphokine. Proc. Natl. Acad. Sci. USA. 89:4447-4451.

26. Bendtzen, K., M. Svenson, V. Jønsson, and E. Hippe. 1990. Autoantibodies to cytokines - friends or foes? Immunol. Today. 11:167-169. 